\title{
PROBLEMATIKA PEMBUKTIAN TERBALIK DALAM PERKARA TINDAK PIDANA KORUPSI
}

\author{
Oleh : Reimon Supusepa \\ Email : reimon.supusepa@gmail.com
}

Fakultas Hukum Universitas Pattimura

\begin{abstract}
Probe principle flips over at ruled Indonesia bases Undang-Undang Nomor 31 Tahun 1999 jo Undang-Undang Nomor 20 Tahun 2001 Remove criminal act of Corruptions. That law applies two probe principles, which is circumscribed upending probe (section 37 and $37 \mathrm{~A}$ ) and pure upending probe (section 12B sentences 1a). But Indonesia until now haven't applied evidence upending as one is managed in that law. Probe that is applied at Indonesia to corruption case is get negative character or up on ground beyond reasonable doubt one that gets orientation on Section rule 183 KUHAP.
\end{abstract}

Keysword : Reverse probe, criminal act of Corruption

\section{A. Pendahuluan}

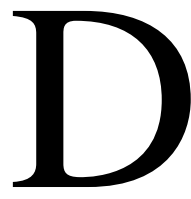
alam Hukum Pidana, pembuktian merupakan suatu sistem yang berada dalam kelompok Hukum Pidana Formil (Hukum Acara). Setelah diberlakukannya Undang-Undang Nomor 8 Tahun 1981 Tentang Kitab Undang-Undang Hukum Acara Pidana (selanjutnya disebut UU No. 8 Tahun 1981), masalah pembuktian diatur secara tegas dalam kelompok Sistem Hukum Formil (Hukum Acara).

Apabila ditelaah mengenai makna "sistem" (hukum pembuktian) maka menurut Martiman Prodjohamidjojo, dapat diartikan sebagai "suatu keseluruhan dari unsur-unsur hukum pembuktian yang berkaitan dan berhubungan satu dengan yang lain serta saling pengaruh mempengaruhi dalam suatu keseluruhan atau 
kebulatan". ${ }^{2}$ Lain halnya dengan, Adami Chazawi mengartikan pembuktian sebagai proses kegiatan untuk membuktikan sesuatu atau menyatakan tentang kebenaran suatu peristiwa. Jadi oleh terdakwa untuk pada akhirnya ditarik suatu kesimpulan mengenai terbukti atau tidaknya terdakwa melakukan perbuatan (tindak) pidana yang didakwakan kepadanya. ${ }^{2}$

Hakekatnya, masalah pembuktian dalam hukum pidana teramat urgent. Apabila dijabarkan, dapat dikatakan pembuktian merupakan suatu proses untuk menentukan dan menyatakan tentang kesalahan seseorang. Konklusi pembuktian ini dilakukan melalui proses peradilan sehingga akan menentukan apakah terdakwa dapat dijatuhkan pidana (veroordeling) karena dari hasil persidangan terbukti secara sah dan meyakinkan melakukan tindak pidana, kemudian dapat pula dibebaskan dari dakwaan (vrijspraak) karena tidak terbukti melakukan tindak pidana, ataukah dilepaskan dari segala tuntutan hukum (onslag van alle rechtsvervolging) karena apa yang didakwakan terbukti namun perbuatan tersebut bukan merupakan suatu tindak pidana. ${ }^{3}$

Dasar sistem pembuktian hukum acara pidana Indonesia terdapat dalam Pasal 183 KUHAP. Pasal ini menyatakan bahwa :

Hakim tidak boleh menjatuhkan pidana kepada seseorang kecuali apabila dengan sekurang-kurangnya dua alat bukti yang sah ia memperoleh keyakinan bahwa suatu tindak pidana benar-benar terjadi dan bahwa terdakwalah yang bersalah melakukannya.

Jadi sebagai suatu lex genaralis, sistem beban pembuktian (umum) dalam perkara tindak pidana dibebankan pada Jaksa Penuntut Umum (JPU). Sehingga Jaksa Penuntut Umum (JPU) harus mempersiapkan alat-alat bukti dan barang bukti secara akurat untuk membuktikan mengenai ada atau tidaknya tindak pidana yang dilakukan oleh seorang terdakwa sebagai konsekuensi logis dari ketentuan tersebut.

${ }^{1}$ Indriyanto Seno Adji, 2016, Korupsi dan Pembalikan Beban Pembuktian,Oemar Seno Adji \& Rekan, Jakarta, hal. 83.

${ }^{2} \mathrm{Ibid}$, hal. 84.

${ }^{3}$ Lilik Mulyadi, 2017, Asas Pembalikan Beban Pembuktian Terhadap Tindak Pidana Korupsi Dalam Sistem Hukum Pidana Indonesia Pasca Konvensi Perserikatan Bangsa-Bangsa Anti Korupsi 2003, Alumni, Bandung, hal. 76. 
Beban pembuktian yang berada pada Jaksa Penuntut Umum (JPU) berkolerasi dengan asas praduga tidak bersalah (presumption of innocent) dan aktualisasi asas tidak mempersalahkan diri sendiri (non self-incrimination). Pembebanan pembuktian ini hakikatnya juga merupakan elaborasi dari asas umum hukum pidana, bahwa siapa yang menuntut, maka dialah yang harus membuktikan kebenaran tuntutannya. ${ }^{4}$

Beban pembuktian oleh Jaksa Penuntut Umum (JPU) berlaku secara umum untuk semua tindak pidana, baik yang ada dalam kodifikasi (Kitab Undangundang Hukum Pidana) maupun di luar kodifikasi. Namun terdapat beberapa pengecualian pada tindak pidana tertentu terutama yang berada di luar KUHP. Salah satunya adalah tindak pidana yang termuat dalam Undang-undang No. 31 Tahun 1999 jo Undang-undang No. 20 Tahun 2001 yang mengatur tentang Pemberantasan Tindak Pidana Korupsi.

\section{B. Pembahasan}

Dalam undang-undang tersebut terdapat ketentuan pemberlakuan mengenai beban pembuktian terbalik, yakni ketentuan mengenai bergesernya beban pembuktian yang semula dibebankan kepada Jaksa Penuntut Umum (JPU) menjadi beban pembuktian yang dibebankan kepada terdakwa. Sehingga terdakwa berperan aktif menyatakan bahwa dirinya bukan sebagai pelaku tindak pidana. Apabila tidak dapat membuktikan, maka terdakwa dinyatakan bersalah melakukan tindak pidana. Ketentuan ini terdapat dalam Pasal 12B ayat (1) huruf a dan b, Pasal 37, Pasal 37 A dan Pasal 38 B.

Dalam penjelasan Pasal 37 Undang-Undang Nomor 31 Tahun 1999 dijelaskan bahwa :

Ketentuan ini merupakan suatu penyimpangan dari ketentuan kitab Undang-Undang Hukum Acara Pidana yang menentukan bahwa jaksa yang wajib membuktikan dilakukannya tindak pidana, bukan terdakwa. Menurut ketentuan ini terdakwa dapat membuktikan bahwa ia tidak

${ }^{4}$ Mahrus Ali, 2019, Hukum Pidana Korupsi Di Indonesia, UII Press, Yogyakarta, hal. 23. 
melakukan tindak pidana korupsi. Apabila terdakwa dapat membuktikan hal tersebut tidak terbukti melakukan korupsi, sebab penuntut umum masih tetap berkewajiban untuk membuktikan dakwaannya. Ketentuan Pasal ini merupakan pembuktian terbalik yang terbatas, karena jaksa masih tetap wajib membuktikan dakwaannya.

Ketentuan mengenai pembalikan beban pembuktian tersebut atau yang dikenal sebagai sistem pembalikan beban pembuktian (Reversal of Burden Proof atau Omkering van Bewijslast) merupakan hasil adopsi dari sistem hukum AngloSaxon atau Negara penganut case-law dan terbatas pada kasus-kasus tertentu (certain cases) khususnya terhadap tindak pidana tentang gratifikasi (gratification) atau pemberian yang berkolerasi dengan suap (bribery). ${ }^{5}$

Pembuktian terbalik merupakan suatu sistem pembuktian yang berada di luar kelaziman teoritis pembuktian dalam hukum acara pidana yang universal. ${ }^{6}$ Alasan utama penerapan pembuktian terbalik adalah karena tindak pidana korupsi ini sangat sulit pemberantasannya, baik karena tindak pidana ini memiliki kualitas pembuktian yang sangat sulit maupun karena tindak pidana korupsi ini biasanya dilakukan oleh para profesional yang memiliki minimal edukasi yang akseptabel bagi kemungkinannya dilakukan kejahatan tersebut. Selain itu, integritas, kapabilitas, dan aktifitas pelaku pada umumnya sangat rentan dengan lingkungan terjadinya tindak pidana korupsi ini. Artinya, pelaku sangat memahami lingkungan kerja dan format untuk menghindari terjadinya pelacakan terhadap kejahatan tindak pidana korupsi ini.

Pada hakikatnya, pembuktian terbalik digunakan sejak penuntut umum membuktikan kesalahan-kesalahan terdakwa. Sebaliknya terdakwa dan penasehat hukumnya akan membuktikan kesalahan-kesalahan penuntut umum, bahwa terdakwa tidak terbukti secara sah dan meyakinkan melakukan tindak pidana yang didakwakan. Selain dari itu ada faktor-faktor tertentu yang menyebabkan terdakwa tidak melakukan pembuktian terbalik yaitu perasaan bersalah, kesalahan-kesalahan yang dibuktikan hakim benar, penegakan hukum dan faktor hukum. Sehingga terdakwa didepan sidang pengadilan yang akan menyiapkan 
segala pembuktian dan apabila tidak dapat membuktikan, terdakwa dinyatakan bersalah melakukan tindak pidana korupsi.

Mahkamah Konstitusi Republik Indonesia dalam Putusannya Nomor 012016- 019-PUU-IV/2006 tanggal 19 Desember 2006, dalam perkara Hak Uji Materiil Undang-Undang Nomor 30 Tahun 2002 tentang Komisi Pemberantasan Tindak Pidana Korupsi (KPK) terhadap Undang-Undang Dasar Negara Republik Indonesia 1945, menyatakan bahwa Mahkamah memandang tindak pidana korupsi yang telah merugikan hak asasi sosial dan ekonomi masyarakat Indonesia adalah suatu kejahatan luar biasa (extra- ordinary crime) dan musuh bersama (common enemy) masyarakat dan bangsa Indonesia secara keseluruhan. ${ }^{7}$

Hal ini sejalan dengan pendapat Romli Atmasasmita bahwa ${ }^{8}$ :

Dengan memperhatikan perkembangan tindak pidana korupsi, baik dari sisi kuantitas maupun dari segi kualitas, dan setelah mengkajinya secara mendalam, maka tidaklah berlebihan jika dikatakan bahwa korupsi di Indonesia bukan merupakan kejahatan biasa (ordinary crime) melainkan sudah merupakan kejahatan yang sangat luar biasa (extra-ordinary crime). Selanjutnya, jika dikaji dari sisi akibat atau dampak negatif yang sangat merusak tatanan kehidupan bangsa Indonesia sejak pemerintahan Orde Baru sampai saat ini, jelas bahwa perbuatan korupsi merupakan perampasan hak ekonomi dan hak sosial rakyat Indonesia.

Penerapan pembuktian terbalik berdasarkan UU Nomor 31 Tahun 1999 jo UU Nomor 20 Tahun 2001 tentang Pemberantasan Tindak Pidana Korupsi ini bukanlah tanpa problem. Hal ini menurut Lilik Mulyadi, dapat dilihat dari kebijakan legislasi pembuatan undang-undang yang produknya masih dapat bersifat multi interprestasi, sehingga relatif banyak ditemukan beberapa kelemahan di dalamnya. ${ }^{9}$

Secara tegas ada kesalahan dan ketidakjelasan perumusan norma tentang pembalikan beban pembuktian dalam ketentuan Pasal 12B Nomor 31 Tahun 1999 jo. UU Nomor 20 Tahun 2001. Ketentuan Pasal 12B ayat (1). Jika dikaji dari perumusan tindak pidana (materiele feit) ketentuan tersebut

${ }^{7}$ Ermansjah Djaja, 2019, Meredesain Pengadilan Tindak Pidana Korupsi, Sinar Grafika, Jakarta, hal. 471.

${ }^{8}$ Lilik Mulyadi, Op. Cit, hlm. 139.

${ }^{9}$ Lilik Mulyadi II, 2018, Bunga Rampai Hukum Pidana; Perspektif Teoritis dan Praktik, Alumni, Bandung, hal. 211. 
menimbulkan kesalahan dan ketidakjelasan norma pembalikan beban pembuktian. Di satu sisi, pembalikan beban pembuktian akan diterapkan kepada penerima gratifikasi berdasarkan Pasal 12B ayat (1) huruf a yang berbunyi, “..yang nilainya Rp. 10.000.000,00 (sepuluh juta rupiah) atau lebih, pembuktian bahwa gratifikasi tersebut bukan merupakan suap dilakukan oleh penerima gratifikasi", akan tetapi di sisi lainnya tidak mungkin diterapkan kepada penerima gratifikasi oleh karena ketentuan pasal tersebut secara tegas mencantumkan redaksional, "setiap gratifikasi kepada pegawai negeri atau penyelenggara Negara dianggap pemberian suap apabila berhubungan dengan jabatannya dan yang berlawanan dengan kewajiban atau tugasnya", maka adanya perumusan semua unsur inti delik dicantumkan secara lengkap dan jelas dalam suatu pasal membawa implikasi yuridis adanya keharusan dan kewajiban Jaksa Penuntut Umum (JPU) untuk membuktikan perumusan delik dalam pasal yang bersangkutan. Tegasnya, ketentuan Pasal tersebut adalah salah susun sehingga apa yang akan dibuktikan sebaliknya malah tidak ada. ${ }^{10}$

Penerapan pembalikan beban pembuktian juga menjadi kebijakan Politik Hukum Pidana yang dilematis karena potensial akan melanggar Hak Asasi Manusia (HAM), dan bertentangan dengan asas praduga tidak bersalah (presumption of innocence) sehingga menimbulkan pergeseran pembuktian menjadi asas praduga bersalah (presumption of guilt) atau asas praduga korupsi (presumption of corruption). Selain itu penerapan pembuktian terbalik bersimpangan dengan ketentuan hukum acara pidana universal yang mensyaratkan terdakwa tidak dibebankan kewajiban pembuktian. ${ }^{11}$

Mencermati pandangan diatas maka UU tindak pidana korupsi mengklasifikasikan pembuktian menjadi 3 (tiga) sistem. Pertama, pembalikan beban pembuktian dibebankan kepada Terdakwa untuk membuktikan dirinya tidak melakukan tindak pidana korupsi. Pembalikan beban pembuktian ini berlaku untuk tindak pidana suap menerima gratifikasi yang nilainya sebesar $\mathrm{Rp}$. 10.000.000,00 (sepuluh juta) rupiah atau lebih (Pasal 12B ayat (1) huruf a) dan

${ }^{10}$ Lilik Mulyadi II, Op. Cit, hal. 211.

${ }^{11}$ Ibid, hal. 215. 
terhadap harta benda yang belum didakwakan yang ada hubungannya dengan tindak pidana korupsi (Pasal 38B). Apabila mengikuti polarisasi pemikiran pembentuk UU sebagai kebijakan legislasi, ada beberapa pembatasan yang ketat terhadap penerapan pembalikan beban pembuktian dikaitkan dengan hadiah yang wajar bagi pejabat. Pembatasan tersebut berorientasi kepada aspek hanya diterapkan kepada pemberian (gratifikasi) dalam delik suap, pemberian tersebut dalam jumlah Rp. 10.000.000,00 atau lebih, berhubungan dengan jabatannya (in zijn bediening) dan yang melakukan pekerjaan yang bertentangan dengan kewajiban (in strijd met zijn plicht) dan harus melapor ke Komisi Pemberantasan Korupsi (KPK).

Kedua, pembalikan beban pembuktian yang bersifat semi terbalik atau berimbang terbalik dimana beban pembuktian diletakan baik terhadap Terdakwa maupun Jaksa Penuntut Umum secara berimbang terhadap obyek pembuktian yang berbeda secara berlawanan (Pasal 37A). Ketiga, sistem konvensional dimana pembuktian tindak pidana korupsi dan kesalahan Terdakwa melakukan tindak pidana korupsi dibebankan sepenuhnya kepada Jaksa Penuntut Umum. Aspek ini dilakukan terhadap tindak pidana suap menerima gratifikasi yang nilainya kurang dari Rp. 10.000.000,00 (sepuluh juta) rupiah (Pasal 12B ayat (1) huruf b) dan tindak pidana korupsi pokok.

Sistem Hukum Pidana Indonesia khususnya terhadap beban pembuktian dalam tindak pidana korupsi secara normatif mengenal asas pembalikan beban pembuktian yang ditujukan terhadap kesalahan orang (Pasal 12B ayat (1), Pasal 37 UU Nomor 31 Tahun 1999 jo UU Nomor 20 Tahun 2001) dan kepemilikan harta kekayaan pelaku tindak pidana korupsi (Pasal 37A, Pasal 38B UU Nomor 31 Tahun 1999 jo UU Nomor 20 Tahun 2001). Secara kronologis pembalikan beban pembuktian bermula dari sistem pembuktian yang dikenal dari negara penganut rumpun Anglo-Saxon terbatas pada "certain cases” khususnya terhadap tindak pidana "gratification" atau pemberian yang berkorelasi dengan "bribery" (suap), misalnya seperti di United Kingdom of Great Britain, Republik Singapura dan Malaysia. Di United Kingdom of Great Britain atas dasar "Prevention of Corruption Act 1916" terdapat pengaturan apa yang dinamakan "Praduga korupsi 
untuk kasus-kasus tertentu" (Presumption of corruption in certain cases) $)^{12}$.

Bertolak dari pemahaman konseptual terhadap prinsip pembalikan beban pembuktian, maka ketentuan Pasal 37 dan Pasal 37A Undang-Undang Nomor 20 Tahun 2001 belum dapat dikatakan telah mengintroduksi sistem pembalikan beban pembuktian. Paling tidak ada dua hal yang dapat di kemukakan untuk mengatakan demikian, yaitu :

Pertama, ketentuan itu belum meletakkan sama sekali kewajiban pembuktian pada Terdakwa; dan penuntut umum tidak dibebaskan dari kewajiban pembuktian tentang kesalahan Terdakwa; Kedua, dalam hal terdakwa dapat membuktikan bahwa ia tidak bersalah, itu belum dapat digunakan sepenuhnya untuk membebaskannya dari dakwaan. Atau sebaliknya, dalam hal ia tidak dapat membuktikan, maka dengan demikian belum dapat digunakan untuk mengatakan bahwa ia telah terbukti melakukan tindak pidana korupsi. Dalam hubungan itu masih diperlukan alat-alat bukti yang lain

Praktik perkara korupsi di Indonesia pada tataran aplikasinya tidak mempergunakan pembalikan beban pembuktian, padahal perangkat hukum memberikan hak kepada Terdakwa dan penasehat hukumnya, Jaksa Penuntut Umum maupun majelis hakim untuk menerapkan pembalikan beban pembuktian baik terhadap kesalahan Terdakwa maupun tentang kepemilikan harta benda Terdakwa yang di duga kuat melakukan tindak pidana korupsi. Adapun alasanalasan tidak di pergunakan pembuktian terbalik adalah :

1. Ditemukan adanya ketidak jelasan dan ketidaksinkronan perumusan norma pembalikan beban pembuktian dalam kebijakan legislasi tindak pidana korupsi di Indonesia disebabkan ketentuan tersebut salah susun, karena seluruh bagian inti delik disebutkan sehingga yang tersisa untuk dibuktikan sebaliknya tidak ada. Konsekuensi logis dimensi demikian menimbulkan asumsi bahwa pembalikan beban pembuktian relatif ada dalam kebijakan formulasi, tetapi tiada dan tidak dapat di terapkan dalam kebijakan aplikatif.

\footnotetext{
${ }^{12}$ www.penghunilangit.com. Diakses pada tanggal 13 Oktober 2018
} 
2. Apabila Terdakwa dan atau penasehat hukumnya akan menggunakan haknya melakukan pembalikan beban pembuktian, relatif akan sulit untuk membuktikan secara negatif ketidakbersalahannya melakukan tindak pidana korupsi dikarenakan adanya kelemahan dalam mengumpulkan alat bukti karena aspek administrasi yang kurang tertata rapi. Disamping itu juga, korelasi dengan aspek korupsi yang tidak bersifat sendirian, tetapi dilakukan beberapa orang, relatif tidak mungkin untuk mendapatkan bukti- bukti guna dapat mendukung ketidakbersalahan seorang pelaku melakukan tindak pidana korupsi.

Dimensi substansial demikian kiranya yang menjadi kendala mengapa "hak" untuk melakukan pembuktian terbalik tindak pidana korupsi pada praktiknya tidak pernah dilakukan.

\section{Penutup}

Dalam prakteknya belum diterapkannya prinsip pembuktian terbalik dalam tindak pidana korupsi, maka perlu adanya penyempurnaan pada KUHAP yang mengakomodir mengenai pembuktian terbalik. Mengingat, seiring dengan kemajuan zaman dan teknologi yang membawa dampak pada perkembangan Tindak Pidana Korupsi yang semakin rumit dan beragam. 


\section{Daftar Pustaka}

\section{Buku :}

Indriyanto Seno Adji, 2016 Korupsi dan Pembalikan Beban Pembuktian, Oemar Seno Adji \& Rekan. Jakarta

Lilik Mulyadi, 2017. Asas Pembalikan Beban Pembuktian Terhadap Tindak Pidana Korupsi Dalam Sistem Hukum Pidana Indonesia Pasca Konvensi Perserikatan Bangsa-Bangsa Anti Korupsi 2003, Alumni. Bandung

Mahrus Ali, Hukum Pidana Korupsi Di Indonesia, Yogyakarta: UII Press.

Ermansjah Djaja, 2019. Meredesain Pengadilan Tindak Pidana Korupsi, Jakarta: Sinar Grafika.

Lilik Mulyadi II, 2018. Bunga Rampai Hukum Pidana: Perspektif Teoritis dan Praktik, Bandung: Alumni.

\section{Internet :}

www.penghunilangit.com 